\title{
SISTEM INFORMASI SUMBER DAYA MANUSIA DALAM MENDUKUNG PERENCANAAN STRATEGIS PERUSAHAAN
}

\author{
Noerlina \\ Jurusan komputer Akuntansi, Fakultas Ilmu Komputer, Binus University \\ Jl. KH. Syahdan No. 9, Palmerah, Jakarta Barat 11480. \\ nurlina@binus.edu
}

\begin{abstract}
Human resources information systems within the company is required to support the activities of senior management (executives) and as a solution to address the needs of the executives by providing the ease of information collection and decision making. The results of this research is the an information system construction which is the beneficial for the executives in decision-making and for human resources in strategic planning. Thus, precise as well as qualified executive decisions will be produced, which will ultimately increase the productivity of human resources in achieving the corporate goals.
\end{abstract}

Keywords: information system, human resources.

\begin{abstract}
ABSTRAK
Sistem informasi sumber daya manusia dalam perusahaan diperlukan untuk mendukung kegiatan manajemen tingkat atas (eksekutif) dan sebagai salah satu solusi menjawab kebutuhan eksekutif dengan memberikan kemudahan dalam hal penerimaan informasi serta pengambilan keputusan. Hasil dari penelitian ini adalah dibangunnya suatu sistem informasi yang bermanfaat bagi eksekutif di dalam pengambilan keputusan serta perencanaan strategis bidang sumber daya manusia. Dengan demikian, keputusan eksekutif yang tepat dan berkualitas akan dapat dihasilkan, yang pada akhirnya akan dapat meningkatkan produktifitas sumber daya manusia dalam mencapai tujuan perusahaan.
\end{abstract}

Kata kunci: sistem informasi, sumber daya manusia 


\section{PENDAHULUAN}

Dalam suatu perusahaan terdapat bermacam-macam sumber daya yang harus dikelola untuk dapat mencapai tujuan, di antaranya sumber daya manusia sebagai sumber daya yang terpenting, karena manusia adalah satu-satunya sumber daya yang dapat mengolah, mengkoordinasikan, dan mengorganisir sumber daya lainnya yang ada di dalam perusahaan. Tanpa adanya sumber daya manusia yang tepat - walaupun suatu perusahaan telah memiliki berbagai fasilitas yang canggih dan modern - tujuan perusahaan tersebut tidak akan tercapai.

Pengembangan sistem informasi eksekutif yang baik dapat menyajikan informasi yang akurat, terbaru dan informatif guna mendukung upaya eksekutif dalam pengarahan kebijaksanaan, sasaran, strategi serta pengendalian visi dan misi.

\section{Ruang lingkup}

Ruang lingkup penelitian ini meliputi: (1) perekrutan - perencanaan perekrutan, aktualisasi perekrutan dan informasi pelamar yang potensial bagi kebutuhan di masa yang akan datang; (2) penilaian kinerja - penilaian umum perusahaan dan masing-masing karyawan; (3) pelatihan dan pengembangan - pelatihan: perencanaan pelatihan yang terdiri atas perencanaan untuk peserta dan biaya, aktualisasi pelatihan dan history pelatihan setiap karyawan. Pengembangan: mutasi promosi dan perincian mutasi promosi tiap karyawan; (4) perputaran karyawan - informasi perputaran karyawan dan perincian perputaran karyawan.

\section{Tujuan}

Adapun tujuan penulisan artikel ini adalah mengidentifikasi dan menganalisis kebutuhan eksekutif akan informasi sumber daya manusia dan merancang sistem informasi sumber daya manusia sesuai dengan kebutuhan manajemen perusahaan.

\section{METODE}

Ada dua metode yang digunakan, yaitu metode analisis yang terdiri dari survei sistem, analisis terhadap temuan survei, identifikasi informasi yang dibutuhkan oleh eksekutif, dan identifikasi persyaratan sistem yang ideal; dan metode perancangan yang berupa rancangan layar.

\section{Kajian Pustaka}

Menurut O'Brien (2003, p.306), Executive Information System adalah sistem informasi yang menggabungkan banyak bentuk dari sistem informasi manajemen dan sistem pendukung pengambilan keputusan yang tujuan utamanya adalah menyediakan bagi para eksekutif akses yang segera dan mudah dalam memperoleh informasi tentang critical success factor dari perusahaan.

Turban (2001, p.310) menyatakan beberapa karakteristik dari sistem informasi eksekutif, yaitu drill down, critical success factor, status access, analysis, exception reporting, use of colors, navigation of information, dan communication.

Sementara definisi menurut Hasibuan (2001, p.10) adalah "Manajemen sumber daya manusia adalah ilmu dan seni mengatur hubungan dan peranan tenaga kerja agar efektif dan efisien membantu terwujudnya tujuan perusahaan, karyawan, dan masyarakat." 
"Penilaian prestasi adalah kegiatan manajer untuk mengevaluasi perilaku prestasi kerja karyawan serta mendapat kebijaksanaannya selanjutnya. Penilaian perilaku yaitu menilai kesetiaan, kejujuran, kepemimpinan, kerjasama, loyalitas, dedikasi, dan partisipasi karyawan. Penilaian prestasi kerja adalah menilai rasio hasil kerja nyata dengan standar, baik kualitas maupun kuantitas yang dihasilkan oleh setiap individu karyawan. Menetapkan kebijaksanaan berarti apakah karyawan akan dipromosikan, didemosikan, dan atau balas jasanya dinaikkan." (Hasibuan, 2001, p.87).

Mutasi adalah perubahan posisi/jabatan, tempat, pekerjaan yang dilakukan baik secara horizontal maupun vertikal (promosi/demosi) di dalam suatu organisasi. Ada dua jenis mutasi. Pertama, mutasi horizontal (job rotation/transfer) yang artinya perubahan tempat atau jabatan karyawan tetapi masih ada ranking yang sama dalam organisasi tersebut. Mutasi ini mencakup "mutasi tempat dan mutasi jabatan". Kedua, mutasi cara vertikal yang berarti perubahan posisi atau jabatan atau pekerjaan, promosi atau demosi, sehingga kewajiban dan kekuasaannya juga berubah. Promosi memperbesar authority dan responsibility, sedangkan demosi mengurangi authority dan responsibility seorang karyawan.

\section{HASIL DAN PEMBAHASAN}

Critical Success Factor pada perusahaan yang berkaitan dengan sumber daya manusia adalah kinerja sumber daya manusia yang tinggi, sehingga kesuksesan perusahaan di dalam mewujudkan kepuasan semaksimal mungkin kepada para pelanggan dapat diraih secara optimal.

Ada tiga aspek yang sangat berpengaruh terhadap tingkat kinerja sumber daya manusia. Pertama, penempatan karyawan pada posisi yang tepat (placement). Penempatan karyawan pada posisi yang tepat akan mendorong karyawan untuk selalu bekerja seoptimal mungkin. Dengan adanya pengembangan karyawan berdasarkan dari penilaian kinerja yang baik, latar belakang pendidikan serta training yang telah didapat, karyawan dapat memperoleh kesempatan untuk dipromosikan atau dimutasikan pada posisi yang tepat, sehingga dapat meningkatkan produktivitas karyawan tersebut. Kedua, pelatihan yang diberikan oleh perusahaan (training). Dengan adanya pelatihan yang efektif, maka kemampuan karyawan dapat terus ditingkatkan sehingga karyawan siap dalam menghadapi tuntutan pekerjaan. Hal ini juga dapat memotivasi karyawan di dalam melaksanakan pekerjaannya, sehingga meningkatkan kinerja karyawan. Dan ketiga, penilaian kinerja karyawan. Penilaian kinerja yang dilakukan secara teratur misalnya satu kali dalam setahun oleh atasan karyawan masing-masing untuk mengetahui tingkat kemampuan, tingkat pengetahuan dan tingkat penguasaan karyawan tersebut dalam melakukan tugas-tugasnya.

\section{Analisis Kebutuhan}

Analisis kebutuhan adalah sebagai berikut: (1) informasi mengenai sumber daya manusia perusahaan dikaitkan dengan perekrutan, pengembangan dan pelatihan, penilaian kinerja dan perputaran karyawan; (2) informasi mengenai perbandingan antara rencana dan realita pada perekrutan dan pelatihan; (3) informasi mengenai setiap karyawan dalam tiap divisi sehubungan dengan histori pengembangan dan pelatihan; (4) informasi mengenai pelamar yang potensial guna memudahkan pihak perusahaan mendapatkan karyawan baru sehingga menghemat waktu dan biaya; (5) informasi eksternal, yaitu peraturan - peraturan pemerintah dan informasi ketenagakerjaan.

\section{Rancangan Layar}

Berikut adalah beberapa rancangan layar yang akan dibuat (Gambar 1-4). 


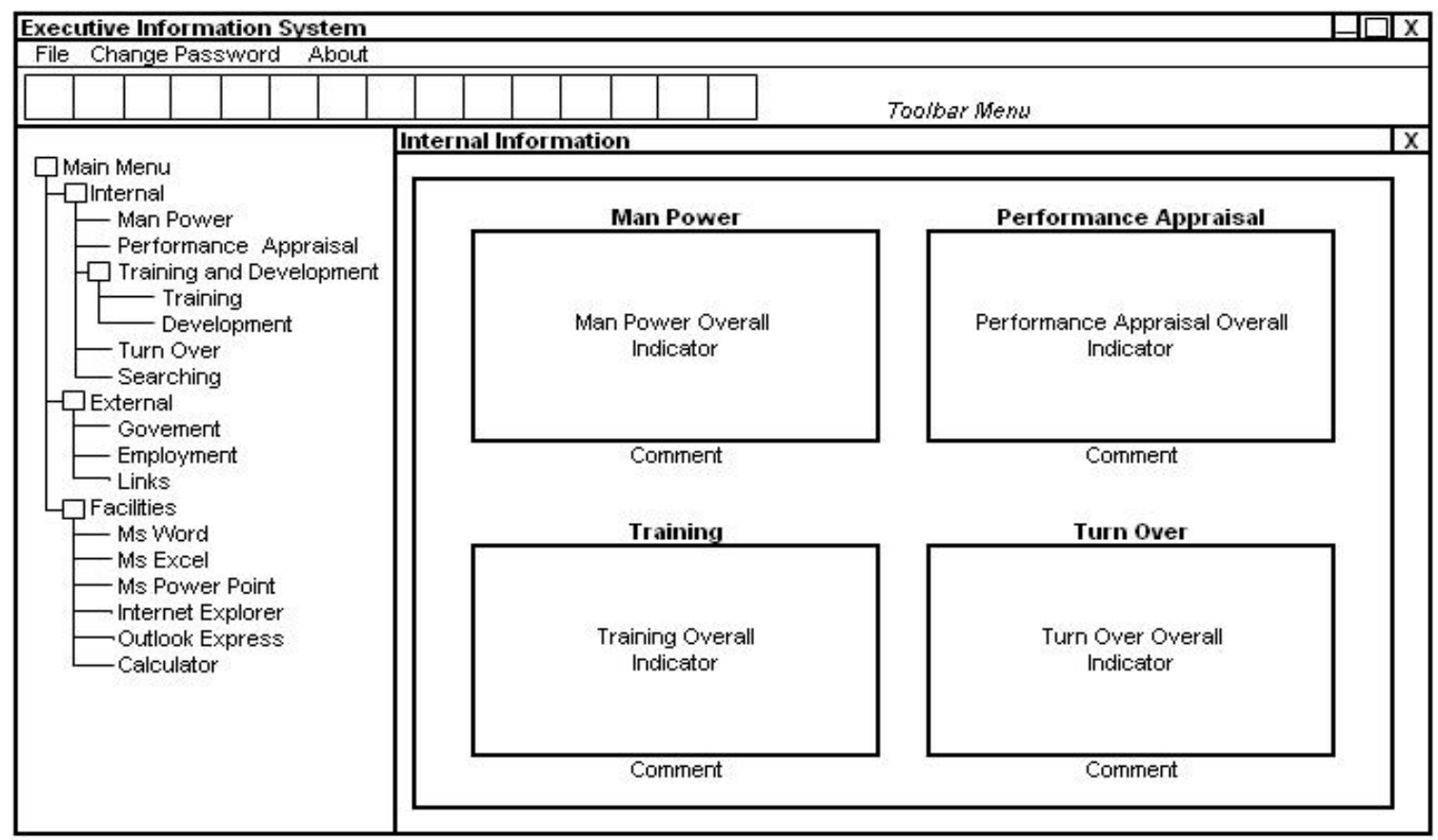

Gambar 1. Rancangan layar indikator internal perusahaan.

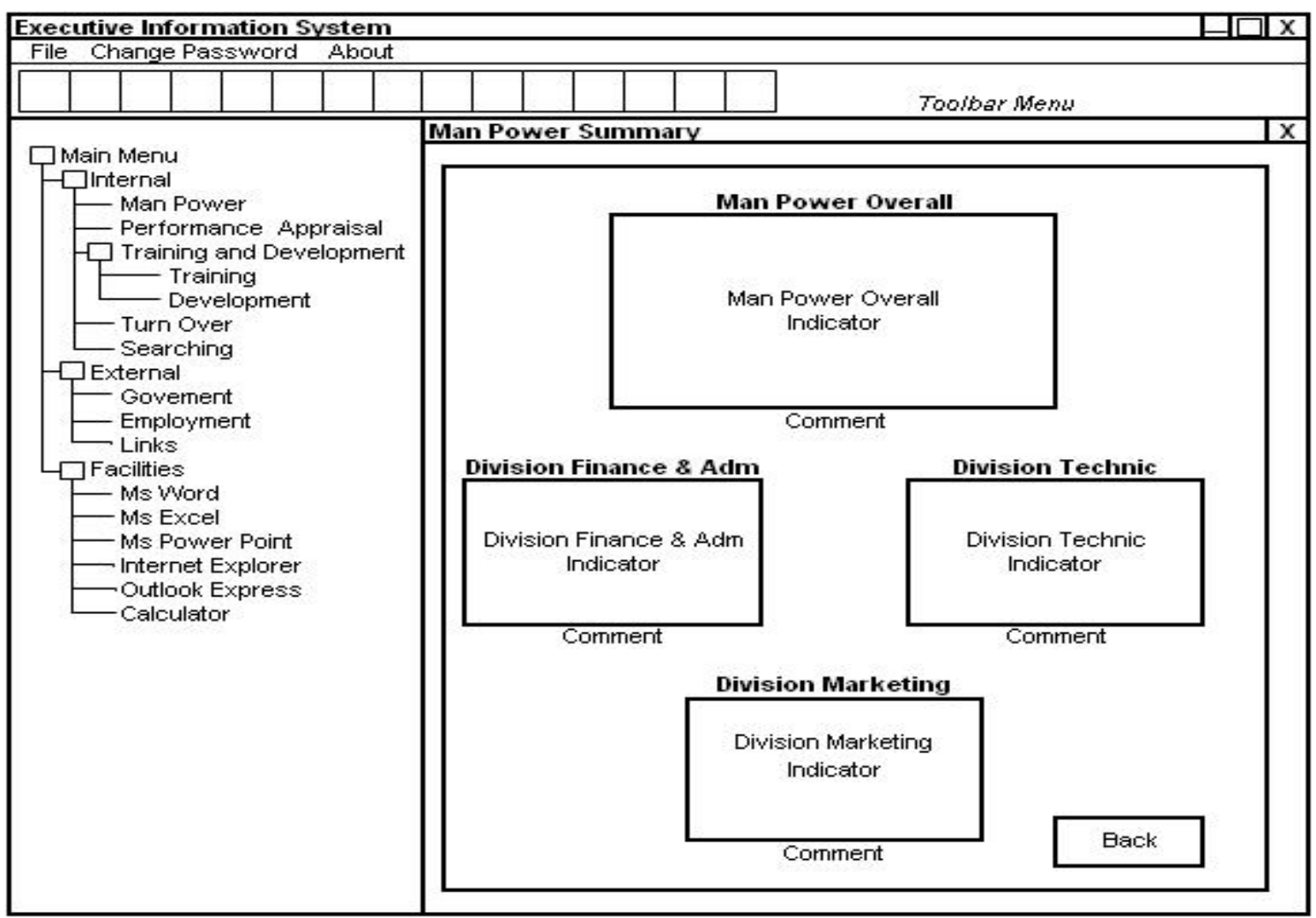

Gambar 2. Rancangan layar indikator man power summary. 


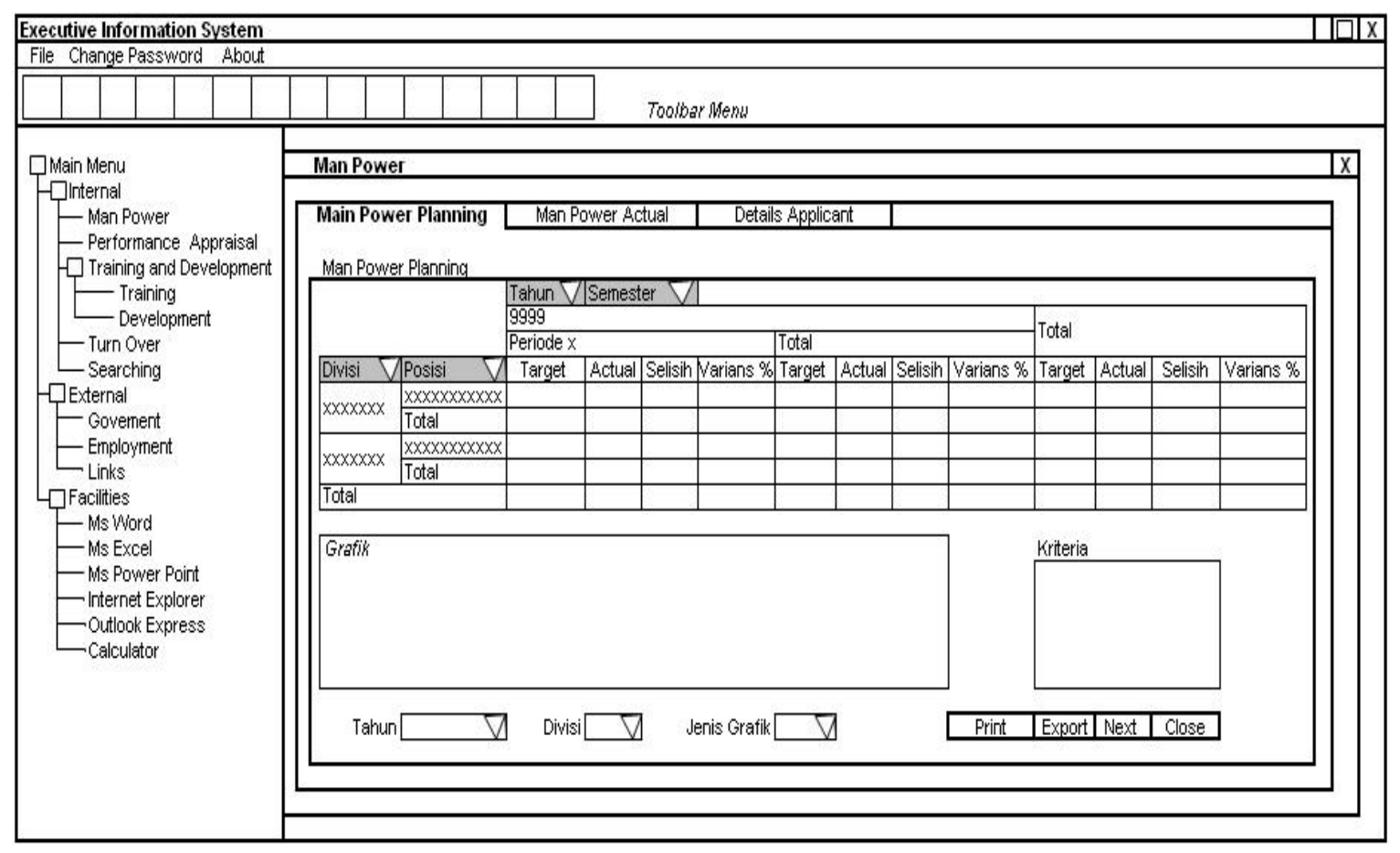

Gambar 3. Layar man power planning.

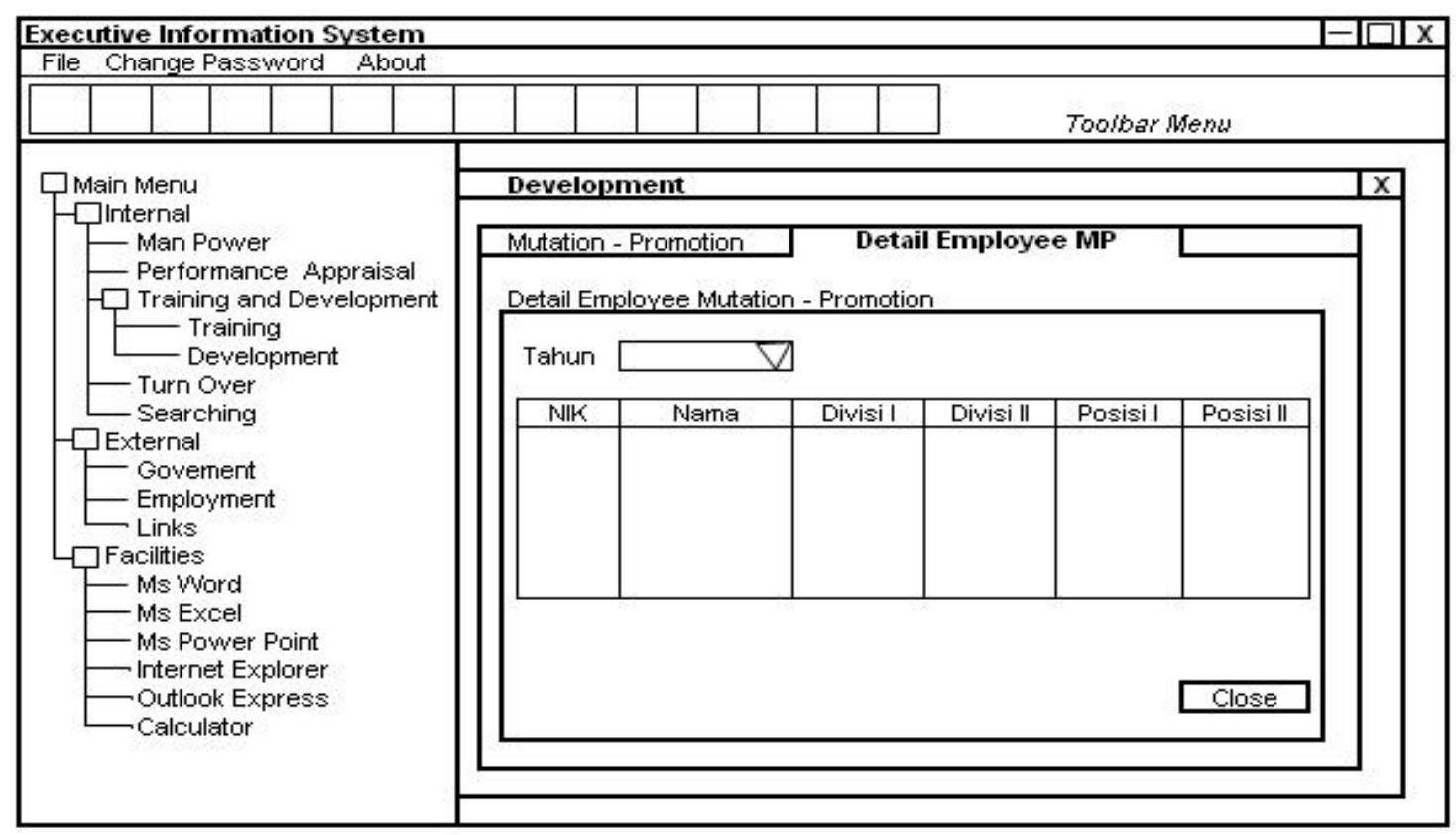

Gambar 4. Rancangan layar Development - Detail Employee Mutation Promotion.

\section{PENUTUP}

Sistem Informasi sumber daya manusia yang dibutuhkan oleh perusahaan minimal harus menyediakan fasilitas dan kemampuan sebagai berikut: (1) Indikator-indikator dan exceptional report yang dapat membantu eksekutif untuk mengidentifikasikan secara cepat dan akurat apabila terdapat 
aspek yang bermasalah dalam sumber daya manusia di perusahaan, misalnya indikator perekrutan, pelatihan, penilaian kinerja, turn over karyawan dan indikator per divisi; (2) Fasilitas drill down, drill up dan drill across sehingga eksekutif dapat memperoleh informasi yang lebih rinci; (3) Dengan adanya indikator dan grafik, eksekutif dapat menganalisa hubungan antara berbagai aspek dalam sumber daya manusia perusahaan. Misalkan hubungan antara jenjang pendidikan karyawan dan jenisjenis pelatihan seperti apa yang perlu diberikan kepada karyawan untuk meningkatkan kemampuan karyawan

\section{DAFTAR PUSTAKA}

Hasibuan, Malayu. S. P. (2001). Manajemen Sumber Daya, Cetakan keempat. Jakarta: Bumi Aksara.

O'Brien, A. J. (2003). Introduction to Information System: Essential For The Internet E-Business Enterprise, (ed. 11). New York: McGraw Hill.

Turban, E. \& Aronson, E. J. (2001). Decision Support and Intelligent Systems, (6 ${ }^{\text {th }}$ ed.). New Jersey: Prentice Hall. 